\title{
СОЦИАЛЬНЫЕ ФУНКЦИИ РЕЛИГИИ: ЦЕРКОВЬ КАК СОЦИАЛЬНЬЙ ИНСТИТУТ ПЕРЕДАЧИ КУЛЬТУРНО-ИСТОРИЧЕСКИХ ТРАДИЦИЙ
}

\section{SOCIAL FUNCTIONS OF RELIGION: THE CHURCH AS A SOCIAL INSTITUTION FOR THE TRANSMISSION OF CULTURAL AND HISTORICAL TRADITIONS}

\section{T. Petukhova}

Summary: The article is devoted to the problem of preserving «places of memory" and the role of the church in this social process. The Church occupies one of the key places in the system of social institutions. It is the church, regardless of the difference of faiths, that has preserved and transmitted stable cultural traditions for centuries.

Keywords: social functions, church, culture, traditions, society, historica memory.

\author{
Петухова Татьяна Николаевна \\ К.ю.н., дочент, ФГБОУВО «Уральский \\ институm ГПС МЧС России» \\ tatyana.petukhova@mail.ru
}

Аннотация: (татья посвящена проблеме сохранения «мест памяти» и роли церкви в этом социальном процессе. Церковь занимает одно из ключевых мест в системе социальных институтов. Именно церковь, независимо от различия конфессий, на протяжении веков сохраняет и передает устойчивые культурные традиции.

Ключевые слова: социальные функции, церковь, культура, традиции, общество, историческая память. ри оценке социальной роли религии, которая реализуется в функциях церкви, имеющих социальный характер, следует обозначить актуальность такой социальной проблемы как сохранение исторической памяти и значение церкви в решении этой проблемы. С чем связана значимость этого вопроса?

«Мы живем в эпоху всемирного торжества памяти. В последние двадцать или двадцать пять лет все страны, все социальные, этнические и семейные группы пережили глубокое изменение традиционного отношения к прошлому.

Формы этого изменения многообразны: критика официальных версий истории и возвращение на поверхность вытесненных составляющих исторического процесса; восстановление следов уничтоженного или отнятого прошлого; культ корней (roots) и развитие генеалогических изысканий; бурное развитие всяческих мемориальных мероприятий; юридическое сведение счетов с прошлым; рост числа разнообразнейших музеев; повышенная чувствительность к сбору архивов и к открытию доступа к ним; возобновившаяся привязанность к «наследию» - тому, что в англоязычном мире называется «heritage», а во Франции — «patrimoine». В каком бы сочетании ни выступали эти элементы, мир затопила нахлынувшая волна вспоминания, прочно соединив верность прошлому - действительному или воображаемому - с чувством принадлежности, с коллективным сознанием и индивидуальным самосознани- ем, с памятью и идентичностью» - это ярко выраженная позиция французского учёного Пьера Нора, с которой, на наш взгляд, нельзя не согласиться. Именно им введен термин «места памяти», широко применимый в современной научной литературе. [3].

В своих работах ученый поднимает проблему целостности материального и духовного. Единство памяти, как комплекса высших психических функций, относящихся к накоплению, сохранению и воспроизведению знаний, и вещественного воплощения (памятники, ордена, письма и т.д.) формирует национальную, в том числе историческую, память того наследия, которое передается последующим поколениям.

Пьер Нора исследует проблемы с многочисленными местами памяти, поскольку «нет памяти уходящих в прошлое социальных групп» [4].

Он утверждает, что: «Память - это жизнь, носителями которой всегда выступают живые социальные группы, и в этом смысле она находится в процессе постоянной эволюции, она открыта диалектике запоминания и амнезии, не отдает себе отчета в своих последовательных деформациях, подвластна всем использованиям и манипуляциям, способна на длительные скрытые периоды и внезапные оживления.

Чувство непрерывности находит свое убежище в местах памяти. Многочисленные места памяти (lieux de 
mémoire) существуют потому, что больше нет памяти социальных групп [5].

Поддерживая мнение ученого, хотелось бы обратиться к такому социальному институту как церковь. Религиозные организации различных конфессий выполняют социальные функции: интегративную, мировоззренческую, регулятивную, психотерапевтическую, коммуникативную и другие, носящие универсальный характер, проявляющиеся в любом типе религиозной практики.

Наряду с ними особое внимание в современный период искажения и переписывания истории, исходя их политической конъюнктуры, заслуживает функция сохранения и передачи культурно-исторического наследия, которой традиционно придерживается церковь.

Именно её стержневой характер подчеркнул Президент Российской Федерации В.В. Путин на встрече с представителями религиозных объединений в честь Дня народного единства в 2020 г.: «Традиции доброго, уважительного отношения между людьми разных национальностей и вероисповеданий завещаны нам нашими предками. Но этим живым духовным наследием, опытом создания уникальной цивилизации мало просто гордиться. Конечно, мы вправе и должны гордиться этим. Но этого недостаточно. Их надо беречь, укреплять и развивать. Это наш общий долг перед нынешним, да и перед будущими поколениями.

Важно понимать, что в мире происходят глубочайшие перемены. С серьёзными вызовами сталкиваются традиционные ценности. Сложнейшие, крайне чувствительные вопросы межнациональных и межрелигиозных отношений становятся, к сожалению, подчас предметом спекуляций, нечистоплотных геополитических игр. На них пытаются паразитировать экстремисты и радикалы, разжигая взаимную ненависть и вражду» [6].

Следует отметить религиозные формы передачи культурных традиций, одной из которых является сохранение исторической памяти религиозными организациями различных конфессий, такие как священные книги, житие святых, картины художников, иконопись, монументальные храмовые здания, некоторые из которых выступают, как сооружения, сохранившие память о прошедших культурно-исторических событиях.

Так, в России традиционно создавались церкви в почтение многознаменательных исторических событий. Это были долгожданные победы над противником, действия, связанные с княжением и царствованием видных государственных деятелей, что неразделимо сопряжено с историей храмоздательства. Так в память о заступниках Отечества или ярких победах создавались церквимонументы, часовни, незабываемые знаки, а также еди- ные сложные комплексы.

Пример тому: Храм Василия Блаженного (Покровский собор) в Москве, Казанский собор в Санкт-Петербурге, Храм Христа Спасителя в Москве, Свято-Троицкая Александро-Невская лавра в Санкт-Петербурге, Свято-Троицкая Сергиева лавра в Сергиевом Посаде, Храм Спас на Крови в Санкт-Петербурге на месте убийства Александра II Освободителя, Церковь-памятник на крови во имя Всех Святых в земле Российской просиявших в Екатеринбурге, неразрывно связанная с убийством Николая II, членов его семьи и домочадцев и т.д.

\section{Следует вылелить некоторые из них.}

Например, храм Василия Блаженного - один из наиболее красочных, а также известных монументов древнерусского зодчества. В 1552 г. в почтение победы полков Ивана Грозного в борьбе за завоевание Казанского и Астраханского ханства был заложен монастырь, преждеосвященный в почтение Священный Троицы. В 1554 г. Иван Грозный дал распоряжение создать на его участке храм Покрова Богородицы с приделами, прославлявшими победу над татарами. Храм в народе назывался Покрова на Рву: храм был создан вблизи с глубочайшим рвом, пролегавшим по стенкам Кремля. Позже в одной из границ собора был погребен Василий Блаженный, вследствие чего храм получил свое новейшее наименование.

Казанский собор в Санкт-Петербурге является памятником церковного зодчества. Возведенный в 1801-1811 г. архитектором Андреем Воронихиным для хранения чтимого списка чудотворной иконы Божией Матери Казанской, собор сейчас ассоциируется с победой в Отечественной войне 1812 года. Именно здесь находятся мощи полководца Кутузова М. Прихожане поклоняются и иконе (религиозный символ), и мощам (символ ратный). Рядом с собором - памятники фельдмаршалам Кутузову М. и М. Барклаю-де-Толли. Симбиоз этих сооружений воспринимается как торжество русского оружия и народной воли в Отечественной войне 1812 года.

Несомненно, храм на Руси считается основным хранителем православной культуры.

Благодаря храмостроительству в течение десяти столетий развивались и все разновидности духовного художества, сопряженные с богослужением. Данные монументы по-прежнему являются нитями, объединяющие народ, православие, культуру и историю.

Кроме того, одной из форм передачи культурноисторической памяти становится орденская система, которая зародилась при Петре І. Названия орденам за ратные подвиги давали в честь святых покровителей 
России, тем самым объединяя исторические события и духовную идеологию.

Так, первым учрежденным орденом стал Орден Святого Апостола Андрея Первозванного, высшая награда XVIII века. Андрей Первозванный считался учеником Иисуса Христа, был распространителем христианства, являлся покровителем России [1]. В постсоветский период Президент Российской Федерации Б.Н. Ельцин Указом от 1 июля 1998 г. № 757 «О восстановлении ордена Святого апостола Андрея Первозванного» [2] воссоздал его. Орден обладает статусом высшей награды Российской Федерации.

Орден святого Победоносца Георгия, учрежденный Екатериной II в 1769 г. являлся наградой отличия офицера, присваивался за боевые подвиги. На ордене изображён всадник Георгий, который пронзает мечем дракона. Орден имеет четыре степени награждения. Первая степень являлась самой почётной, за первую степень добавлялось 700 рублей к пенсии. Первой степень обозначалась звездой на левой груди, через правое плечо лента с большим крестом. Вторая степень обозначалась звездой на левой груди, а также крест на шее. Третья степень - малый крест на шее. Четвертая степень - малый крест на колодке. Обладатели ордена любой степени приобретали дворянство, получали ежегодную добавку к пенсии. За всю историю России орденом Георгия Победоносца была награждена всего одна женщина. Раиса Михайловна Ивановна - сестра милосердия, заменившая убитого командира в годы Первой мировой войны, ее подвиг был посмертно отмечен четвертой степенью ордена Георгия Победоносца [2]. Орден восстановлен в России как государственная награда в 2000 году.

С этапа возникновения первого постоянного войска в России появилась культурно-историческая традиция иметь православным воинам собственных небесных благодетелей. В дореволюционной России все без исключения, кто имел армейскую форму, безусловно, по- лагали собственным благодетелем архангела Михаила. Однако воздушный флот, особенно почитал Илью Пророка. Покровителями конницы являлись святые Флор и Лавр. Святой Георгий Победоносец благодетельствовал казачеству. В абсолютно всех армейских составляющих возводили церкви в название обожаемых священных. Современные Вооруженные Силы России данные устои также соблюдают, передавая традиции восприятия святости ратных дел угодных Богу. Практически у любого рода войск имеется собственный небесный защитник.

Так, например, основной покровитель Вооруженных сил Русской Федерации, а также Сухопутных войск является святой праведник Георгий Победоносец. Георгий выдержал все без исключения страдания и не отказался от Христа.

Покровителем Воздушно-десантных полков является пророк Илия. Второго августа отмечается праздник российских Воздушно-десантных войск. Данный день так же считается днем пророка Илии, в его почтение ведутся литургии, а также устраивается крестный ход. Священный пророк Илия, величайший из пророков Ветхого Завета, с небольших лет отдал себя Господу, живя в пустыне, придерживаясь строгого пост и молитв.

Покровительницей Ракетных войск является непорочная праведница Варвара, принявшая крещение без разрешения отца, перенесшая муки за веру. Сразу после захоронения около ее мощей начались удивительные исцеления.

Несомненно, после распада СССР церковь восполняет идеологическую нишу, учитывая закрепленный в Конституции Российской Федерации отказ государства от государственной идеологии. Тем самым, церковь, как социальный институт, создавая и сохраняя «места памяти», выступает одним из адептов выполнения социальной функции: передачи культурно-исторических традиций свойственными только ей способами.

\section{ЛИТЕРАТУРА}

1. Дуров В.А. Русские награды XVIII- начала XX веков. М. - Просвещение, 1997. - с. 9

2. Кузнецов А.А. Награды: Энциклопедический путеводитель по истории российских наград. / пер. и доп. - М.: Современник, 2003. - с. 438.

3. Нора П. Всемирное торжество памяти / журнал «Тransit». - 2002. - № 22.

4. Нора П. и др. Проблематика мест памяти. СПб.: Изд-во С.-Петерб. ун-та, 1999, с. 17-50.

5. Нора П. и др. Франция — память. СПб.: Изд-во С.-Петерб. ун-та, 1999, с. 17-50.

6. Стенограмма выступления В.В. Путина на встрече с представителями религиозных объединений. Режим доступа: http://prezident.org/tekst/ stenogramma-vystuplenija-putina-na-vstreche-s-predstaviteljami-religioznyh-obedinenii-04-11-2020.html

7. Указ № 757 «0 восстановлении ордена Святого апостола Андрея Первозванного». Режим доступа: https://base.garant.ru/1576929 